\title{
VALUE STREAM MAPPING (VSM) PADA INSTALASI RAWAT INAP DI RUMAH SAKIT PEMBINA KESEJAHTERAAN UMAT (PKU) MUHAMMADIYAH GOMBONG
}

\author{
Titi Istinganah Muyasarroh1, Marsiana Wibowo ${ }^{*}$ \\ 1,2Fakultas Kesehatan Masyarakat, Universitas Ahmad Dahlan, Yogyakarta, Indonesia \\ *Email: marsiana.wibowo@ikm.uad.ac.id
}

\begin{abstract}
ABSTRAK
Value Stream Mapping (VSM) merupakan gambaran aktivitas pelayanan dari pertama kali konsumen meminta pelayanan hingga selesainya pelayanan. Rumah sakit menggunakan VSM untuk mengidentifikasi Value Added (VA) dan Non Value Added (NVA). Tujuan penelitian adalah menganalisis aliran proses pelayanan rawat inap VSM untuk mengetahui VA dan NVA. Peneliti menggunakan pendekatan kualitatif dengan rancangan studi kasus. Subjek terdiri dari petugas pendaftaran, perawat rawat inap, kepala instalasi rawat inap, apoteker farmasi rawat inap, kasir rawat inap, dan pasien rawat inap BPJS serta umum. Peneliti melakukan wawancara dan observasi pelayanan pasien BPJS dan pasien umum. Hasil menunjukkan waktu proses penerimaan pasien BPJS adalah 6.111 detik dan pasien umum adalah 5.465 detik. Waktu proses pemulangan pasien BPJS adalah 11.877 detik dan pasien umum 7.904 detik. Perbandingan VA dan NVA proses penerimaan pasien rawat inap BPJS 52\%:48\%, pasien umum yaitu 49\%:51\%. Pada proses pemulangan pasien BPJS 20\%:80\%, dan pasien umum 40\%:60\%. Baik pasien umum maupun BPJS memiliki waktu tunggu yang lama masuk bangsal. Proses pemulangan pasien BPJS berdurasi lebih lama dibandingkan pasien umum. Hasil observasi menunjukkan adanya waste waiting, conclusion, defect, transportation dan overproccesing. Rumah sakit perlu menindaklanjuti hasil ini agar pelayanan rawat inap lebih efektif dan efisien.
\end{abstract}

Kata kunci: rawat inap, value stream mapping

\begin{abstract}
Value Stream Mapping (VSM) is a description of service activities from the first time consumers request service until the completion of service. Hospitals use VSM to identify Value Added (VA) and Non Value Added (NVA). The research objective aimed to analysis the process flow of VSM to find VA and NVA. The researcher used a qualitative approach with a case study design. The subjects were registration officer, inpatient nurses, the heads of inpatient installation, inpatient pharmacist, inpatient cashiers, the Healthcare and Social Security Agency (HSSA) and general patients of inpatients. Researchers conducted interviews and observations of the services of the HSSA and general patients. The results showed the time for the HSSA admission was 6,111 seconds and the general was 5,465 seconds. The HSSA patient returning process was 11,877 seconds and general was 7,904 seconds. Comparison of VA and NVA process of the HSSA inpatient admission was 52\%:48\%, general patients were 49\%:51\%. In the process of returning HSSA patients 20\%:80\%, and general 40\%:60\%. Both general patients and the HSSA have a long waiting time. The HSSA process of returning patients had a longer duration than it used to be.
\end{abstract}


Observation results indicated the existence of waste waiting, conclusion, defect, transportation and overprocessing. Hospitals needed to follow up on these results so that services were more effective and efficient.

Keywords: inpatient, value stream mapping

\section{PENDAHULUAN}

Rumah sakit sebagai penyedia layanan kesehatan harus memiliki mutu pelayanan yang baik dan meningkat secara berkesinambungan. Oleh karena itu, evaluasi dan perbaikan harus terus dilakukan (Safitri I, 2017). Rawat inap merupakan revenue center rumah sakit, maka harus ada efisiensi dalam prosesnya. Proses pelayanan harus dilakukan secara efisien, karena pelayanan yang lambat akan meningkatkan kondisi pasien selanjutnya (outcome) serta dapat meningkatkan morbiditas dan mortalitas. Pasien yang mengalami penundaan masuk unit rawat inap bisa mengalami perawatan yang lebih lama sehingga biaya perawatan juga meningkat (Huang Q, dkk, 2019) serta meningkatkan risiko meningkatnya infeksi nosocomial (Sihombing N, 2014).

Metode lean merupakan metode yang digunakan untuk menghapus aktivitas tidak bernilai tambah sehingga setiap aktivitas dapat memberikan nilai tambah. Efektifitas metode lean telah terdokumentasi dalam berbagai penelitian, termasuk implementasi di institusi rumah sakit. Identifikasi value adalah langkah pertama dalam implementasi prinsip lean. Value adalah aktivitas yang berperan langsung untuk memenuhi kepuasan pasien, sedangkan aktivitas yang tidak memiliki nilai tambah akan menghasilkan pemborosan (Graban M, 2014). Penghitungan waktu proses pelayanan UGD di RSUD Bekasi telah mampu mengidentifikasi waste selama proses penanganan. Melalui VSM yang dihasilkan, didapat solusi untuk perbaikan, yaitu dengan flow dengan cycle cell, pull dengan facemmaker, visual management heijunka, dan $5 \mathrm{~S}(\mathrm{~V} \mathrm{M}$, 2017). VSM terbukti sebagai alat yang ideal untuk menghilangkan waste dan mengurangi waktu tunggu pelayanan kesehatan (Haron SHA dan Ramlan R, 2015). Beberapa permasalahan yang dialami pada pelayanan rawat inap Rumah Sakit PKU Muhammadiyah Gombong adalah pasien tidak membawa berkas secara lengkap, sehingga waktu tunggu lebih lama, waktu tunggu masuk ruang rawat inap lama, serta waktu tunggu kepulangan pasien yang lama. Tujuan dari penelitian ini adalah menganalisis aliran proses pelayanan rawat inap di Rumah Sakit PKU Muhammadiyah Gombong dengan VSM.

\section{METODE PENELITIAN}

Metode yang digunakan dalam penelitian ini adalah kualitatif dengan pendekatan studi kasus. Studi kasus merupakan pendekatan untuk mengeksplorasi suatu masalah dengan batasan terperinci dengan pengambilan data yang mendalam, mengertakan berbagai sumber informasi. Lokasi penelitian yaitu Instalasi rawat inap Rumah Sakit PKU Muhammadiyah Gombong. Subjek penelitian dipilih secara purposif, yaitu orang-orang yang terlibat langsung dan dapat memberikan informasi yang relevan dan memadai tentang tujuan penelitian. Teknik pengambilan data yang digunakan adalah wawancara, observasi, dan telaah dokumen. Peneliti melakukan wawancara kepada kepala instalasi rawat inap, perawat rawat inap, petugas pendaftaran rawat inap, farmasi rawat inap, kasir rawat inap dan pasien rawat inap. Peneliti melakukan observasi proses pelayanan kepada 40 pasien. Jumlah ini ditentukan berdasarkan rata-rata jumlah 
pasien masuk dan pulang per hari yang diambil dengan teknik acak sederhana. Peneliti menelaah dokumen yang terdiri dari alur proses pasien, arsip pedoman/standar pelayanan, dan denah rawat inap.

\section{HASIL DAN DISKUSI}

Value stream mapping (VSM) proses pelayanan pasien rawat inap terbagi menjadi pasien BPJS dan umum. VSM penerimaan pasien BPJS tersaji pada gambar 1 dan VSM penerimaan pasien umum tersaji pada gambar 2. VSM kepulangan pasien BPJS tersaji pada gambar 3 dan VSM kepulangan pasien umum tersaji pada gambar 4 . Rumus penghitungan dalam VSM sebagai berikut:

1. Lead Time $(\mathrm{LT})=\mathrm{CT}+\mathrm{WT}$
3. $N V A=N V A / L T \times 100 \%$

4. $\mathrm{NNVA}=N N V A / L T \times 100 \%$

Keterangan :

1. WT $($ Waiting Time $)=$ waktu tunggu pasien tanpa melakukan aktivitas

2. LT (Lead Time) = waktu pelayanan keseluruhan

3. $\mathrm{CT}$ (Cycle Time) = waktu pasien mendapatkan pelayanan

4. VA (Value added) = aktivitas yang memberikan nilai tambah

5. NVA (Non Value added) = aktivitas yang tidak memberikan nilai tambah

6. NNVA (Non Necessary Value Added) = aktivitas yang tidak memberikan nilai tambah tapi tidak dapat dihindari/dihilangkan

2. $\mathrm{VA}=V A / L T \times 100 \%$

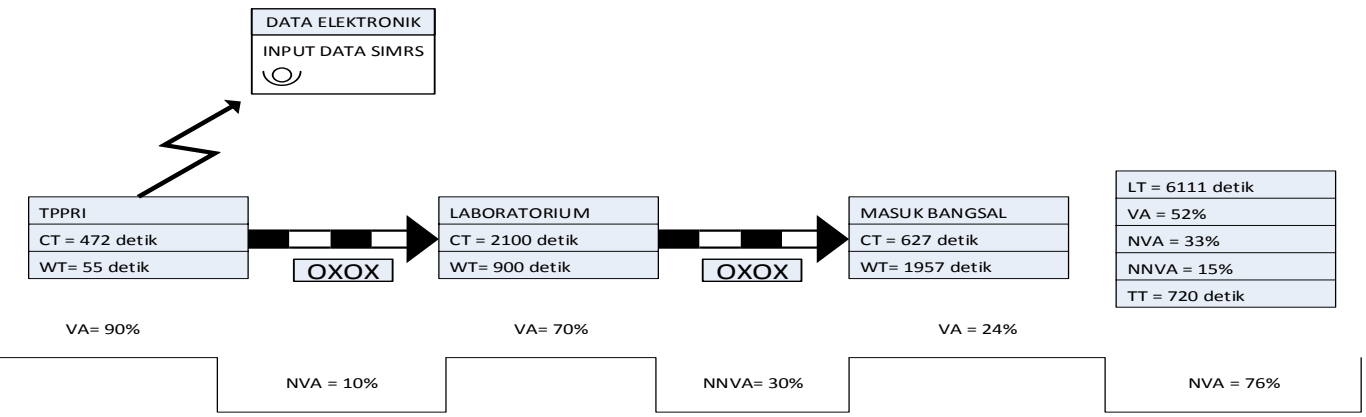

Gambar 1. VSM Penerimaan Pasien pada Pasien BPJS

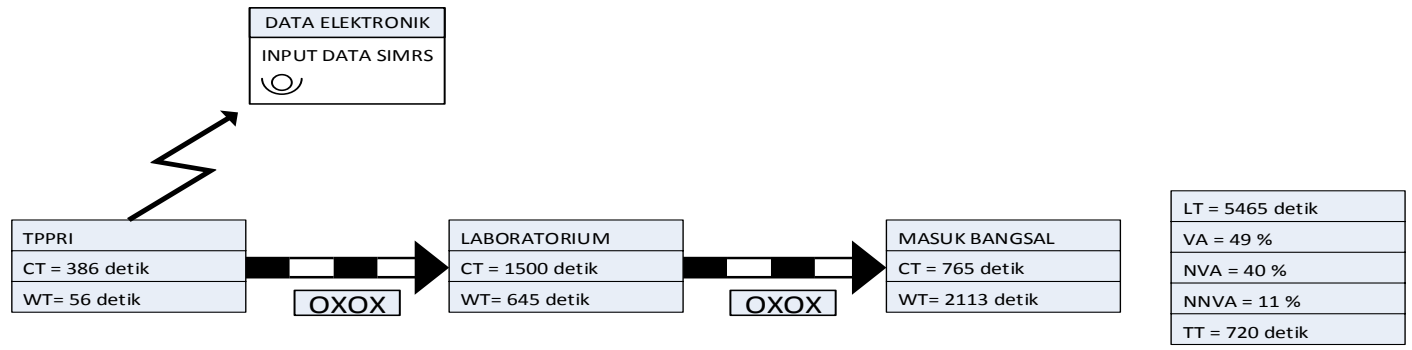

$\mathrm{VA}=90 \%$

$\mathrm{VA}=69 \%$

$V A=27 \%$

NVA $=10 \%$

NNVA $=31 \%$

NVA $=73 \%$

Gambar 2. VSM Penerimaan Pasien pada Pasien umum 


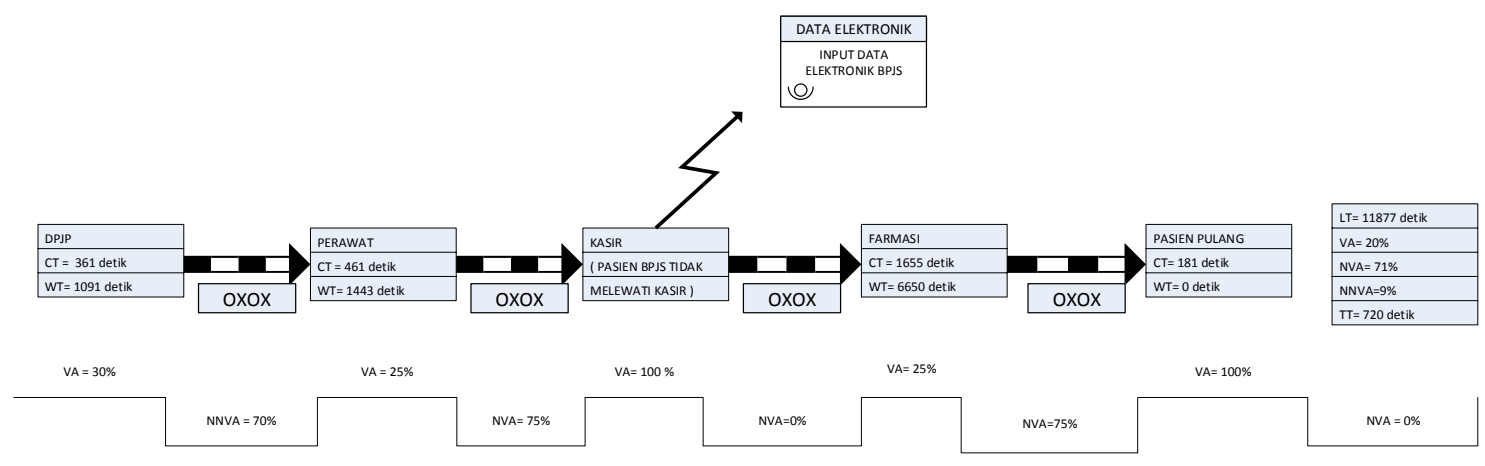

Gambar 3. VSM Kepulangan Pasien pada Pasien BPJS

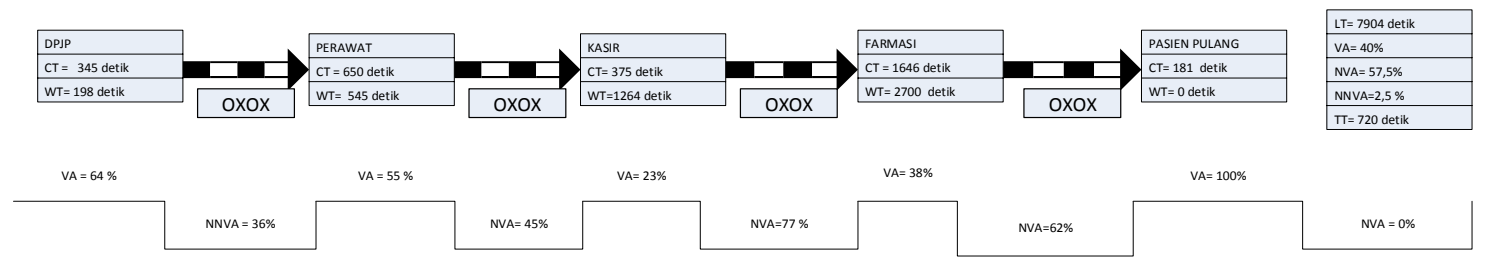

Gambar 4. VSM Kepulangan Pasien pada Pasien umum

Waktu penerimaan dan pemulangan pasien pada pasien BPJS adalah 6.111 detik dan 11.877 detik. Waktu penerimaan dan pemulangan pasien umum adalah 5.465 detik dan 7.904 detik. Berdasarkan hasil penghitungan VSM pada proses penerimaan pasien BPJS terdapat VA 52\% dan pasien umum 49\%. Sedangkan pada proses pemulangan pasien BPJS terdapat VA 20\% dan pasien umum $40 \%$.

Pelayanan pasien yang BPJS lebih lama dibandingkan pasien umum diantarnya dikarenakan pasien BPJS perlu menunjukkan syarat-syarat BPJS dan verifikasi kartu BPJS. Masih terdapat pasien BPJS yang tidak membawa persyaratan secara lengkap. Pada proses laboratorium, terdapat nilai NNVA yaitu kegiatan yang tidak menambah nilai bagi pasien namun tidak dapat dihindari. Kegiatan tersebut adalah kegiatan menunggu hasil laboratorium. Berdasarkan observasi, hasil lab pasien yang berkategori tidak darurat diantar ke bangsal apabila pasien telah mendapatkan kamar, sedangkan pasien yang berkategori darurat/emergency maka akan ditandai sebagai pemeriksaan cito yaitu pemeriksaan yang hasilnya harus segera dilaporkan. Berdasarkan observasi yang dilakukan peneliti, durasi pelayanan penerimaan pasein, rata-rata pasien menunggu 30 menit sampai 2 jam untuk mendapatkan kamar dan pindah ke bangsal. Rumah Sakit PKU Muhammadiyah Gombong tidak memiliki standart waktu tunggu untuk mendapatkan kamar, hal ini disesuaikan dengan kondisi di bangsal. Rumah sakit ini merupakan rumah sakit yang berprinsip syariah dan berlandaskan nilai Islami sehingga pasien laki-laki dan pasien perempuan akan dibedakan pada tiap ruang kamar. Hasil observasi dilapangan, ditemukan fakta bahwa ada beberapa pasien yang tidak perlu menunggu kamar kosong. Hal ini dapat terjadi apabila jumlah pemulangan pasien cukup banyak pada hari itu, atau pasien BPJS memilih untuk naik kelas. Keterbatasan ruangan perawatan, yang ditandai dengan jumlah pasien dan bed occupancy rate (BOR) pasien yang cukup banyak sebesar 75\%, menyebabkan ada 
keterlambatan memindahkan atau transfer pasien ke ruangan rawat inap. Hal ini tentu akan berpengaruh terhadap lama dari waktu tunggu (boarding) pasien di IGD (Deviantony F, dkk, 2017).

Berdasarkan observasi pada 20 pasien BPJS dan 20 pasien umum, didapatkan ratarata waktu pelayanan pemulangan pasien pada pasien BPJS adalah 11.877 detik dan pasien umum adalah 7.904 detik. Aktivitas pelayanan kepulangan pasien yang terlama adalah aktivitas apoteker menyiapkan obat pasien dan retur obat, baik pada pasien BPJS maupun umum. Cross FunctionalFlowchart kepulangan pasien dapat dilihat pada Lampiran 3. Berdasarkan hasil observasi dilapangan dan hasil wawancara, tidak ada jadwal pasti dari DPJP untuk visit. Hal ini disebabkan DPJP memiliki tugas lain selain di rawat inap yaitu di rawat jalan, DPJP akan datang lebih awal atau terlambat. Hal ini menyebabkan waktu tunggu pasien menjadi semakin lama. Waktu tunggu pasien sangat mempengaruhi kepuasan pasien terhadap pelayanan. Terdapat hubungan yang kuat antara kepuasan pasien dengan ketepatan jam kedatangan dokter (David D, dkk, 2014). Kepuasan pasien pada dimensi reliability dikatakan baik dan puas dengan kualitas pelayanan yang dirasakan karena pasien merasa bahwa kehandalan yang dimiliki petugas sudah baik yang menyatakan bahwa pelayanan dokter kepada pasien BPJS tepat waktu (Siswati S, 2016). Keterlambatan kedatangan dokter visit juga dapat menyebabkan proses pemulangan tertunda semakin lama. Selain itu semakin banyak pasien pulang, maka waktu tunggu resume dan resep akan semakin lama. Pada proses ini terjadi bottleneck yaitu proses pemulangan pasien pertama berhenti karena dokter akan menyerahkan resume pasien apabila telah selesai untuk semua pasien.

Proses selanjutnya adalah proses administrasi kepulangan pasien oleh perawat, pada setiap bangsal memiliki kondisi yang berbeda-beda. Salah satunya pada bangsal Multazam memiliki jumlah tempat tidur sebanyak 53 TT, dengan SDM perawat setiap shiftnya adalah 4 perawat dan 1 petugas umum. Perbandingan pasien dengan jumlah SDM yang tidak seimbang menyebabkan waktu tunggu administrasi semakin lama. Perawat yang bertanggung jawab atas pemulangan pasien hanya satu, dan hasil pengamatan pada saat penelitian, perawat masih harus melayani pasien lain, keluarga pasien dan pada jam besuk juga ikut melayani tamu yang bertanya. Hal tersebut menyebabkan hambatan perawat dalam proses administrasi semakin besar. Rumah Sakit PKU Muhammadiyah Gombong telah menerapkan lean management, khususnya lean SDM. Salah satu indikator keberhasilan rumah sakit yang efektif dan efisien adalah tersedianya SDM yang cukup dengan kualitas yang tinggi, profesional yang sesuai dengan fungsi dan tugas personil. Jumlah SDM yang cukup diiringi dengan komitmen profesional. BOR, jumlah jam perawatan pasien selama 24 jam berpengaruh terhadap kebutuhan jumlah tenaga perawat pada instalasi rawat inap RSUD Mamuju Utara (Sade S, dkk, 2012).

Pada proses pemulangan pasien, NVA paling tinggi adalah pada proses menunggu obat dari farmasi yaitu $75 \%$ pada pasien BPJS dan $62 \%$ pada pasien umum. Rata-rata waktu tunggu di farmasi pada pasien BPJS adalah 6.650 detik dan pada pasien umum adalah 2.700 detik. Perbedaan selisih waktu tunggu disebabkan jumlah pasien yang berbeda, jumlah pasien BPJS lebih banyak dibandingkan dengan pasien umum. Sedangkan rumah sakit memiliki aturan bahwa untuk resep pasien umum akan didahulukan prosesnya. Hal ini disebabkan pasien masih harus melanjutkan proses di kasir. Penyebab waktu tunggu di unit farmasi adalah farmasi rawat inap memiliki tugas lain yaitu melayani pasien dari poli bedah. Selain itu jumlah SDM yang ada pada setiap shiftnya adalah 3-4 orang. Menurut petugas farmasi 
jumlah tersebut masih kurang untuk melayani obat pasien dari 2 unit. Lama waktu tunggu pasien juga dipengaruhi oleh hari pelayanan. Apabila pelayanan poli bedah rawat jalan buka, maka jumlah pasien akan meningkat dan waktu tunggu akan semakin lama. Aktivitas-aktivitas kecil seperti menerima resep dari perawat, melayani pasien yang bertanya juga dapat mempengaruhi waktu tunggu. Kepuasan pasien salah satunya dipengaruhi oleh waktu tunggu pelayanan (Pratiwai MR dan Sani FN, 2017).

Proses terakhir dari proses pemulangan adalah proses di kasir. Proses di kasir rawat inap hanya dilewati oleh pasien umum dan pasien BPJS naik kelas. Sedangkan pasien BPJS yang biasa lembar keuangan akan diproses langsung oleh petugas BPJS. Proses waktu tunggu di unit kasir yaitu pada saat menunggu rekapan tagihan dari unit farmasi dan mengantri di kasir. Lama waktu tunggu pada unit kasir disebabkan oleh rekapan tagihan dari farmasi dan antrian dikasir yang bersamaan dengan pasien rawat jalan. Kasir rawat inap dan kasir rawat jalan digabung menjadi satu ruang, dan jumlah petugas hanya berjumlah dua orang hal tersebut menjadi penyebab waktu tunggu. Dampak dari tertundanya kepulangan pasien adalah resiko infeksi nosokomial, terlambat pengobatan dan tindakan, timbul kejenuhan, bertambahnya hari dan biaya rawat, dampak pada rumah sakit LOS memanjang, tertundanya pasien masuk, dan menurunnya kepuasan pelanggan (Rahayuningsih, 2014).

KepMenkes RI Nomor 129 tahun 2008 tentang Standar Pelayanan Minimal Rumah Sakit menyebutkan bahwa standar waktu pemberian informasi tagihan pasien rawat inap adalah $\leq 2$ jam (Kementerian Kesehatan RI, 2008). Data penelitian untuk total waktu proses pemulangan rata-rata adalah 11.877 detik untuk pasien BPJS dan 7.904 detik pada pasien umum. Hal ini menunjukkan bahwa proses discharge yang termasuk proses penerimaan tagihan melebihi standar yang ditetapkan oleh KepMenkes RI (Rahayunungsih, 2014). Kegiatan-kegiatan yang berkategori value added dalam proses pelayanan rawat inap adalah kegiatankegiatan yang dilaksanakan sesuai dengan SPO rumah sakit. SPO adalah sekumpulan prosedur operasional standar yang digunakan sebagai pedoman dalam perusahaan untuk memastikan langkah kerja setiap anggota telah berjalan secara efektif dan konsisten, serta memenuhi standar dan sistematika. Dapat dilihat dalam hasil VSM bahwa total nilai VA pada kedua pasien di proses penerimaan pasien sudah mencapai lebih dari $30 \%$, sehingga dapat dikatakan proses penerimaan pasien sudah berjalan dengan efektif (Kementerian Kesehatan RI, 2008).

Pasien dengan proses pemulangan selesai dapat dilaporkan sebagai bed tersedia. Penyiapan bed pasien baru sekitar 15 menit. Namun, ada pasien yang sudah melunasi pembayaran tetapi belum meninggalkan ruangan, sedangkan banyak waiting list di IGD. Pasien belum meninggalkan ruang rawat inap disebabkan beberapa faktor, diantaranya menunggu injeksi terakhir, menunggu alat kesehatan dari rumah sakit, menunggu jemputan dari pihak keluarga pasien, menunggu mobil ambulance dari rumah sakit. Berdasarkan Permenkes No. 24 tahun 2016 setiap rumah sakit harus memiliki ruang tunggu dengan kapasitas yang memadai dan harus dipisahkan ruang tunggu untuk pasien dengan penyakit menular. Menurut peneliti, kurangnya fasilitas ruang tunggu untuk pasien pulang juga merupakan hambatan pada proses penerimaan dan pemulangan pasien. Karena proses pemulangan pasien sangat berpengaruh pada proses penerimaan pasien kaitannya dengan manajemen tempat tidur. Pasien dari IGD tidak dapat masuk ke kamar rawat inap jika kamar tersebut belum dalam keadaan kosong (Tambunan RM, 2013). Dari uraian tersebut menunjukkan bahwa penyebab waktu tunggu pasien masuk bangsal adalah proses 
pemulangan pasien yang lama. Titik waktu tunggu paling lama pada proses pemulangan pasien adalah proses administrasi dan farmasi. Akar masalah panjangnya waktu tunggu proses administratif pemulangan pasien di rumah sakit, karena berbagai hal saling berkaitan di ruang perawatan, instalasi farmasi, dan bagian administrasi. Akar masalah utama yang dapat diidentifikasi adalah dalam hal sistem, SDM, dan sarana prasarana di ketiga unit tersebut(14).

\section{KESIMPULAN}

Terdapat aktivitas yang mengandung VA dan NVA di Pelayanan Rawat Inap RS PKU Muhammadiyah Gombong, baik pada pasien BPJS maupun umum.

Aktivitas VA meliputi aktivitas pada pendaftaran pasien rawat inap (petugas menanyakan surat perintah rawat inap dokter, menyiapkan berkas rawat inap, menunjukkan syarat-syarat pasien asuransi/BPJS/umum, menjelaskan fasilitas pelayanan rawat inap, menulis kelas sesuai dengan kehendak pasien di buku catatan, penginput data pasien, menginput data pasien ke SIM R, memesankan kamar sesuai pesanan pasien/keluarga, mengkonfirmasi pesanan kamar pasien, menjelaskan hak dan kewajiban pasien disertai tanda tangan educator, membuatkan gelang identitas pasien sesuai jenis kelamin, mencetak SEP untuk pasien BPJS), Pasien masuk bangsal (Petugas IGD mengantarkan pasien menuju kamar, IGD mengkonfirmasi kondisi/status pasien kepada perawat, memindahkan pasien ke bed kamar bangsal, melakukan assessmen awal keperawatan), Kepulangan pasien (Dokter memperbolehkan pasien pulang sesuai kriteria, melakukan resume pasien dan menulis resep, Perawat menyiapkan administrasi lembar keuangan pasien pulang, memulangkan pasien secara SIM RS, merekap obat pasien pulang dan return, mengantarkan resep obat dan returan ke farmasi rawat inap,
Apoteker menyiapkan obat pulang dan retur obat, menginput data tagihan farmasi pasien, mengkonfirmasi kepada perawat untuk mengambil obat pasien pulang, mengkonfirmasi lembar keuangan pasien pulang BPJS kepada admin pasien, Admin pasien mengambil lembar keuangan pasien BPJS di bangsal untuk direkap, mengantarkan lembar keuangan pasien pulang ke kasir, mengkonfirmasi kembali obat pulang ke farmasi rawat inap, mengambil obat pasien pulang, menjelaskan cara penggunaan obat kepada pasien/keluarga, memberikan edukasi perawatan pasien di rumah kepada keluarga pasien, mengantar pasien pulang sampai keluar bangsal).

Aktivtas NVA meliputi Rework (menyalin kembali data pasien ke lembar persetujuan), Waiting (menunggu obat pulang, kasir, pemeriksaan oleh DP JP, hasil laboratorium, hasil coding BPJS, menungggu dipindahkan ke bangsal, menunggu perawat menyelesaikan rekap administrasi), Tranportation (jarak ruang admin dengan kasir jauh, jarak ruang admin dengan ruang BPJS jauh, jarak ruang rawat inap dengan kasir jah, jarak pengiriman berkas RM ke rawat inap jauh, jarak ruang rawat inap dan farmasi jauh), Overprocessing (petugas mengerjakan pekerjaan lain selain tugasnya, petugas berulang kali kepada pasien, pengecekan berulang kali (tidak fokus), konfirmasi berulang terkait obat pulang, menyiapkan obat untuk poli bedah)

\section{Saran}

Berdasarkan NVA transportation dan waiting yang ditemukan, penambahan fasilitas ruang tunggu bagi pasien yang sudah bisa pulang, namun terkendala proses administrasi yang belum selesai adalah saran yang diberikan peneliti, sehingga kamar tersebut dapat disiapkan untuk digunakan pasien yang membutuhkan. Penambahan penunjuk arah yang tepat dapat diimplementasikan agar 
pengunjung mengetahui tata letak ruang di rumah sakit.

\section{DAFTAR PUSTAKA}

SAFITRI I, KAUTSAR AP. Peningkatan Mutu Pelayanan Kesehatan Dirumah Sakit Menggunakan Metode Lean Management. Farmaka [Internet]. 2017 Jul 7 [cited 2019 Apr 3];15(1):47-52. Available from: http://jurnal.unpad.ac.id/farmaka/articl e/view/12685.

Huang Q, Thind A, Dreyer JF, Zaric GS. The impact of delays to admission from the emergency department on inpatient outcomes. BMC Emerg Med [Internet]. 2010 Jul 9 [cited 2019 Apr 3];10(July):16. Available from: http://www.ncbi.nlm.nih.gov/pubmed/ 20618934.

Sihombing N. Analisis Efisiensi Proses Discharge Dan Upaya Peningkatan Efisiensi Dengan Pendekatan Lean Six Sigma Pada Unit Rawat Inap RS St. Elisabeth Bekasi Tahun 2014. Universitas Indonesia; 2014.

Graban M. Lean Hospitals; Improving Quality, Patient Safety, and Employee Engagement. second edi. Boca Raton: CRC Press; 2011.

V M. Kajian Efektivitas Proses Penanganan Pasien UGD Di RSUD Kabupaten Bekasi Dengan Menggunakan Metode Lean Thinking [Internet]. Universitas Gadjah Mada; 2017 [cited 2019 Apr 3]. Available from:

http:/ / etd.repository.ugm.ac.id/index.p hp?mod=penelitian_detail\&sub=Penelitia nDetail\&act $=$ view\&typ $=h t m l \& b u k u \_i d=1$ 10465\&obyek_id=4.

Haron SHA, Ramlan R. Patient Process Flow Improvement: Value Stream Mapping. J Manag Res [Internet]. 2015 Jan 21 [cited 2019 Apr 3];7(2):495. Available from: http://www.macrothink.org/journal/in dex.php/jmr/article/view/6988.

Deviantony F, Ahsan A, Setyoadi S. Analisis Faktor Yang Berhubungan Dengan Waktu Tunggu Pasien Setelah Keputusan Rawat Inap Di Putuskan di Zona Kuning Instalasi Gawat Darurat RSUD dr. Iskak Tulungagung. NurseLine J [Internet]. 2017;2(c):1-4. Available from: https://jurnal.unej.ac.id/index.php/NLJ /article/download/5928/4392/.

David D, Hariyanti T, Widayanti Lestari E. Hubungan Keterlambatan Kedatangan Dokter terhadap Kepuasan Pasien di Instalasi Rawat Jalan. J Kedokt Brawijaya [Internet]. 2014 Aug 3 [cited 2019 Apr 3];28(1):31-5. Available from: http://jkb.ub.ac.id/index.php/jkb/articl e/view/518.

Siswati S. KUALITAS PELAYANAN KESEHATAN DENGAN KEPUASAN PASIEN BPJS DI UNIT RAWAT INAP RSUD KOTA MAKASSAR. Media Kesehat Masy Indones [Internet]. 2016 Jun 22 [cited 2019 Apr 3];11(3):174-83. Available from: http://journal.unhas.ac.id/index.php/m $\mathrm{kmi} /$ article/view/531.

Sade S, Razak A, Thaha RM, Karossa P, Mamuju Utara K, Administrasi Kebijakan Kesehatan B, et al. Kebutuhan Jumlah Tenaga Perawat Berdasarkan Beban Kerja Pada Instalasi Rawat Inap Rsud Mamuju Utara Provinsi Sulawesi Barat An Analysis On The Need Of The Number Of Nurses Based On Work Load In Inpatient Installation Of North Mamuju Public Hospital [Internet]. Universitas Hasanudin; 2012 [cited 2019 Apr 3]. Available from: http://pasca.unhas.ac.id/jurnal/files/15 48bd865667e83c21c60613b50e662c.pdf.

Pratiwi MR, Sani FN. Hubungan Waktu Tunggu Pelayanan Terhadap Tingkat Kepuasan Pasien Di Poliklinik Kebidanan Dan Kandungan Rsud Kota Surakarta. 
Profesi (Profesional Islam Media Publ Penelit [Internet]. 2017 Jul 28 [cited 2019 Apr 3];14(2):24. Available from: https:/ / ejournal.stikespku.ac.id/index.p $\mathrm{hp} / \mathrm{mpp} /$ article/view/211.

Rahayuningsih. Faktor-Faktor Yang Mempengaruhi Keterlambatan Pemulangan Pasien Diruang Rawat Bedahdan Penyakit Dalam Rawat Inap Terpadu Gedung A Rumah Sakit Umum Pusat Nasional Dr. Ciptomangunkusumo Jakarta Pada Tahun 2013 [Internet]. Universitas Gadjah Mada; 2014 [cited 2019 Apr 3]. Available from: http://etd.repository.ugm.ac.id/index.p hp?mod=penelitian_detail\&sub=Penelitia $\underline{\text { nDetail\&act }=\text { view\&typ }=\text { html\&buku_id }=7}$ 3737\&is_local=1.

Kementerian Kesehatan Republik Indonesia. Keputusan Menteri Kesehatan Republik Indonseia Nomor : 129/Menkes/SK/II/2008 tentang Standar Pelayanan Minimal Rumah Sakit [Internet]. Kementerian Kesehatan Republik Indonesia 2008. Available from: http://bprs.kemkes.go.id/v1/uploads/p dffiles/peraturan/6 KMK No. 129 ttg Standar Pelayanan Minimal RS.pdf.

Tambunan RM. Standard Operating Procedures (SOP). Edisi 2. Jakarta: Maeistas Publishing; 2013. 
IAKMI Jurnal Kesehatan Masyarakat Indonesia, Volume 1, No. 1, April 2020

Journal Homepage : http://jurnal.iakmi.id/index.php/IJKMI

ISSN 2721-9437 (Media Online) 